\title{
Pupuk Organik Cair Berbahan Dasar Limbah Ternak untuk Tanaman Sayuran
}

\author{
Saragih Evi Warintan*1, Purwaningsih², Angelina Tethool ${ }^{3}$, Noviyanti ${ }^{4}$ \\ ${ }^{1}$ Program Studi Nutrisi dan Teknologi Pakan Ternak, Fakultas Peternakan Universitas Papua-Manokwari \\ 2,3,4Program Studi Kesehatan Hewan, Fakultas Pertanian Universitas Papua-Manokwari \\ *e-mail: e.saragih@unipa.ac.id¹;p.purwaningsih@unipa.ac.id;angelinanovitatethool@gmail.com³; \\ n.noviyanti@unipa.ac.id ${ }^{4}$
}

\begin{abstract}
Organic fertilizer is known as liquid fertilizer (Pupuk Organik Cair =POC) which is made of through fermentation of some organic matter. It is simple and eficient on application as well as contain high nutrient contain which is ready to use by plant. The activity of the community development focus on how to make POC. Participatory rural approach (PRA) was the methods of the community development activity. Two group of farmers from two villages were participants of this activity. The result showed all the participants were enthusiastic and involved in all the activities which indicated on their presence and asking some questions. It was more than 100 litre POC that harvested as a result of the demonstration of making POC. POC could be enough for 5 ha of vegetables field such as kangkong, spinach and mustard green. POC can also generate income with more than 6,5 billion rupiahs if the price selling was Rp 10.000/bottle (1,5 litre). The POC has been applied to mustard green with $15 \mathrm{ml} / 1$ litre water dosage and showed pretty good growth.
\end{abstract}

Keywords: POC, Goat, fertilizer, community development. farmers

\begin{abstract}
Abstrak
Pupuk Organik Cair (POC) merupakan pupuk berbentuk cair hasil fermentasi berbagai bahan organik. Keunggulan POC dari segi aplikasi yang mudah, dibutuhkan dalam jumlah sedikit dan unsur hara yang langsung tersedia sehingga cepat dimanfaatkan tanaman.Kegiatan ini bertujuan memanfaatkan memanfaatkan limbah ternak menjadi produk yang memiliki nilai tambah dan menjadi solusi penyedian pupuk bagi petani di Kampung Matoa.. Kegiatan pengabdian meliputi penyuluhan, demonstrasi pembuatan POC berbahan kotoran kambing dan daun gamal serta aplikasi POC. Metode participatory rural approach (PRA) digunakan dalam kegiatan peserta peternak kambing di Kampung Prafi Mulya dan Matoa di distrik Prafi Kabupaten Manokwari. Partisipasi masyarakat pada kegiatan cukup tinggi diindikasikan dengan keaktifan dan kehadiran peserta yang 100\% dalam semua kegiatan. Keunggulan POC berbahan dasar kotoran kambing, dosis penggunaan dan aplikasinya adalah hal-hal yang ditnayakan peserta kegiatan. POC yang dihasilkan sebanyak 100 liter. Apabila asumsi penggunaan pupuk cair per ha sebanyak 20 liter, maka produksi POC yang dihasilkan pada kegiatan ini dapat digunakan untuk 5 hektar lahan. Asumsi penjualan POC dengan harga Rp. 10.000/botol (1500 ml) dapat menghasilkan lebih dari Rp 6,5 juta. Aplikasi POC pada tanaman sawi dengan dosis 15 cc/liter air menunjukkan pertumbuhan yang cukup baik. Pengolahan kotoran ternak kambing sebagai bahan baku pupuk organik cair dapat meningkatkan nilai ekonomi limbah ternak. Selain itu produk pupuk yang dihasilkan dapat dimanfaatkan sebagai pupuk alternatif untuk tanaman sayuran.
\end{abstract}

Kata kunci : POC, Kambing, Pupuk, Pengabdian, Peternak

\section{PENDAHULUAN}

Pemakaian pupuk organik kembali menjadi populer dengan adanya kesadaran masyarakat untuk mengkonsumsi produk-produk pertanian dan peternakan organik. Produk pakan organik dianggap lebih sehat karena bebas dari bahan kimia, pestisida dan pupuk sintetik. Hal ini merupakan alasan pertanian organik semakin berkembang. Simanungkalit et al.,(2006) menyatakan bahwa pupuk organik sangat bermanfaat bagi peningkatan produksi pertanian baik kualitas maupun kuantitas, mengurangi pencemaran lingkungan, dan meningkatkan kualitas lahan secara berkelanjutan. Selanjutnya dinyatakan bahwa pupuk organik juga merupakan sumber nitrogen tanah yang utama dan berperan dalam memperbaiki sifak fisik, kimia dan biologi tanah. Penggunaan pupuk organik dalam jangka panjang dapat meningkatkan 
produktivitas lahan dan dapat mencegah degradasi lahan. Untuk mendukung pertanian organik, penyediaan pupuk organik dalam berbagai bentuk mulai diproduksi baik dalam skala rumah tangga maupun industri. Pemakaian pupuk organik kembali menjadi tren di kalangan rumah tangga dan perusahaan pertanian organik. Pada masa pandemi Covid-19, pertanian organik skala rumah tangga menjadi kegiatan yang banyak diminati masyarakat. Hal ini menyebabkan permintaan pupuk organik semakin meningkat.

Pupuk organik merupakan pupuk yang terbentuk dengan adanya proses konversi bahanbahan organik menjadi bahan yang lebih sederhana dengan menggunakan aktivitas mikroba. Peraturan Menteri Pertanian No 1 Tahun 2019 tentang Pendaftaran Pupuk Organik, Pupuk Hayati, dan Pembenah Tanah memberikan definisi pupuk organik secara jelas. Pupuk organik adalah pupuk yang berasal dari tumbuhan mati, kotoran hewan dan/atau bagian hewan (Nurwati et al,. 2017), dan/atau limbah organik lainnya yang telah melalui proses rekayasa, berbentuk padat atau cair dapat diperkaya dengan bahan mineral dan/atau mikroba yang bermanfaat untuk meningkatkan kandungan hara dan bahan organik tanah, serta memperbaiki sifat fisik, kimia, dan/atau biologi tanah. Sumber bahan pupuk organik dapat berasal dari kompos, pupuk hijau, pupuk kandang, sisa panen (jerami, brangkasan, tongkol jagung, bagas tebu, dan sabut kelapa), limbah ternak, limbah industri yang menggunakan bahan pertanian, dan limbah kota (Simanungkalit et al. 2006)

Pupuk organik memegang peranan penting untuk menjamin keberlanjutan pemanfaatan lahan pertanian. Pupuk organik dapat menjamin kesuburan tanah, meningkatkan populasi jasad renik, mempertinggi daya serap dan daya simpan air (Sutedjo, 2010). Pupuk organik dapat berbentuk padat dan berbentuk cair. Pupuk organik padat dikenal dengan pupuk kompos atau pupuk kandang, sedangkan pupuk organik berbentuk cair dikenal dengan Pupuk Organik Cair (POC)(Anwar et al. 2008).

Pupuk organik cair secara sederhana didefinisikan sebagai pupuk organik hasil fermentasi dari beberapa bahan organik. Beberapa ahli mendefinisikan pupuk organik sebagai pupuk yang berasal dari hewan atau tumbuhan yang telah mengalami fermentasi (Simamora, dkk, 2005). Selanjutnya Hadisuwito (2007) menyatakan pupuk organik cair sebagai pupuk larutan yang terdiri dari beberapa unsur hara sebagai hasil pembusukan bahan-bahan organik. Hadisuwito (2012) menyebutkan beberapa kelebihan pupuk organik cair dibandingkan dengan pupuk organik padat antara lain: 1). Mampu mengatasi defisiensi hara secara cepat; 2) Tidak masalah dalam pencucian hara; 3) Mampu menyediakan hara secara cepat bagi tanaman dan 4). Memiliki bahan pengikat sehingga dapat langsung diserap tanaman; 5) Mengandung zat tertentu seperti mikroorganisme jarang terdapat dalam pupuk organik padat dalam bentuk kering. Selanjutnya Ambarwati dan Widya (2007) menjabarkan beberapa manfaat dan kegunaan pupuk organik cair antara lain:

1. Dapat mendorong dan meningkatkan pembentukan klorofil daun dan pembentukan bintil akar pada tanaman leguminosae sehingga meningkatkan kemampuan fotosintesis tanaman dan penyerapan nitrogen dari udara

2. Dapat meningkatkan vigor tanaman sehingga tanaman menjadi kokoh dan kuat, meningkatkan daya tahan tanaman terhadap kekeringan, cekaman cuaca dan serangan patogen penyebab penyakit.

3. Merangsang pertumbuhan cabang produksi.

4. Meningkatkan pembentukan bunga dan bakal buah, serta

5. Mengurangi gugurnya daun, bunga dan bakal buah.

Aplikasi pupuk organik cair telah banyak digunakan dan semakin populer di kalangan pencinta tanaman dan petani. Hal ini disebabkan karena penggunaan pupuk cair lebih efisien dan mudah dalam penggunaan. Beberapa penelitian melaporkan pengunaan pupuk organik cair untuk pemupukan pada kacang hijau (Vigna radiata L .)(Hanisar 2015), kubis bunga (Prastyo 2015), bawang merah (Allium ascalonicum L) (Setiyowati et al. 2010), caisim (Brassica juncea 
L.)(Alakhyar et al. 2019), dan petsai (Brassica Chinensis L)(Napilia 2017). Hal ini menunjukkan bahwa pemanfaatan pupuk organik cair pada tanaman pertanian sudah sangat umum bagi petani.

Petani/peternak di Kampung Matoa pada umumnya menggunakan pupuk buatan untuk kegiatan pertanian. Penggunaan pupuk an organik dalam jangka panjang dapat menurunkan kualitas lahan pertanian. Selain itu, pupuk an organik ketersediaanya terbatas bahkan sering tidak tersedia pada saat dibutuhkan petani. Potensi pupuk organik berbahan dasar kotoran kambing cukup melimpah karena pada umumnya petani memelihara ternak kambing sebagai usaha sampingan. Pengolahan limbah kotoran kambing belum dioptimalkan masyarakat sebagai altenatif pupuk untuk kegiatan pertanian. Untuk itu kegiatan pembuatan pupuk organic cair ini menjadi solusi permasalahan petani dalam hal penyediaan pupuk.

\section{METODE}

Kegiatan pengabdian ini dilakukan menggunakan metode participatory rural approach (PRA) yaitu suatu metode pendidikan kepada masyarakat melalui penyuluhan, pelatihan, demonstrasi/percontohan (demplot) dan pendampingan. Pemilihan metode PRA karena metode ini mempunyai kelebihan diantaranya keterlibatan aktif anggota masyarakat dalam hal ini kelompok mitra sebagai subjek. Kegiatan ini mencakup penyuluhan pembuatan POC dilanjutkan dengan demonstrasi pembuatan POC. Peserta penyuluhan adalah kelompok peternak kambing di Kampung Prafi Mulya dan Kampung Matoa berjumlah 10 orang dan masyarakat di kedua desa yang dengan keinginan sendiri mau terlibat. Pupuk organik yang akan dibuat pada kegiatan ini berbahan baku utama kotoran kambing dan daun Glirisidae sp. Kedua bahan ini akan ditambahkan molases dan EM4 sebagai agen dekomposer. Pemilihan kedua bahan utama ini karena tersedia melimpah di sekitar masyarakat. Pemanfaatan limbah ternak kambing berupa kotoran sebagai pupuk. Daun gamal memiliki kandungan unsur nitrogen yang cukup tinggi. Fahrurrozi et al., (2017) melaporkan daun gamal memiliki 16.8\% bahan kering, 5.04\% nitrogen, $0.32 \%$ phosphor, $6.21 \mathrm{mg} / 100 \mathrm{mg}$ kalium, $12,83 \mathrm{me} / 100$ gr kalsium, 5,83 me/100 g magnesium, $47.7 \%$ organik karbon, $11.89 \%$ selulosa dan 6,105 \% lignin. Bahan yang digunakan untuk pembuatan POC pada kegiatan ini seperti pada Tabel 1 untuk drum plastik kapasitas 250 liter. Kegiatan pengabdian ini dilaksanakan pada bulan agustus 2020.

Tabel 1. Bahan dan alat untuk pembuatan pupuk organik cair berbahan dasar kotoran kambing dan gamal

\begin{tabular}{lll}
\hline Bahan & Satuan & Jumlah \\
\hline Kotoran kambing & $\mathrm{Kg}$ & 30 \\
Daun gamal & $\mathrm{Kg}$ & 75 \\
Gula merah & $\mathrm{Gr}$ & 300 \\
EM4 & $\mathrm{Ml}$ & 120 \\
Air & Secukupnya & $2 / 3$ dari ukuran wadah \\
Drum plastik & $250 \mathrm{~L}$ & 1 \\
Botol plastic bekas & Buah & 1 \\
Selang aerator transparan & Buah & 1 \\
Pisau & Buah & 2 \\
Telenan & Buah & 2 \\
Plakban & Buah & 1 \\
\hline
\end{tabular}

Tahapan pembuatan pupuk organik cair sebagai berikut:

1. Lubangi leher drum atau tutup drum sebesar selang aerator dan tutup botol aqua.

2. Isi air dalam botol aqua hingga $2 / 3$ ukuran botol 
3. Rekatkan tempat selang masuk sehingga tidak ada celah udara. Biarkan ujung selang yang lain masuk kedalam botol yang telah diberi air. Pastikan tidak ada udara yang masuk dan keluar dari lubang aqua dan drum tempat fermentasi

4. Potong/cincang daun gamal yang sudah dipanen. Hal ini bertujuan untuk mempermudah bahan untuk dimasukkan ke dalam drum dan mempercepat proses fermentasi

5. Siapakan bioaktivator dengan cara melarutkan gula merah dengan 5 liter air dicampurkan dengan $120 \mathrm{ml} \mathrm{EM} 4$

6. Isi air ke dalam drum sebanyak setengah drum

7. Tambahkan biokativator ke dalam drum yang berisi air aduk sampai merata

8. Masukkan kotoran kambing dan daun gamal ke dalam drum

9. Tambahkan air hingga $2 / 3$ dari ukuran drum

10. Aduk sampai rata dan tutup rapat drum

11. Biarkan proses fermentasi selama 21 hari

12. Setelah 21 hari, drum dibuka dan apabila tercium aroma seperti tape maka proses fermentasi dan pembuatan pupuk organik cair telah matang

13. Saring air dan isi ke dalam botol yang dituutp dengan rapat. Ampas sisa fermentasi dapat digunakan sebagai pupuk padat

14. Pupuk siap digunakan. Untuk pemakaian pupuk, sebaiknya POC diencerkan dengan dosis 15 cc dengan 1 liter air

15. Aplikasi pupuk dapat disemprotkan atau disiramkan langsung ke tanaman.

Semua proses pembuatan pupuk organik akan terjadi secara anaerob. Untuk memastikan pupuk telah matang, cium aroma dan pastikan tidak berbau busuk. Pupuk cair organik yang matang akan mengeluarkan harum tape. Apabila pupuk di kemas dengan baik maka pupuk organik cair ini dapat disimpan hingga 6 bulan.

\section{HASIL DAN PEMBAHASAN}

Kegiatan penyuluhan berisi tentang pemaparan berbagai pemanfaatan limbah peternakan. Pemanfaatan feses ternak kambing sebagai baku pembuatan pupuk organik cair menjadi fokus utama materi penyuluhan ini (Gambar 1). Langkah-langkah pembuatan pupuk organik cair berbahan baku feses ternak kambing dan daun gamal dijelaskan secara rinci sehingga mudah dipahami peserta penyuluhan. Penjelasan tentang kelebihan dan kekurangan pupuk organik cair dibandingkan dengan pupuk organik padat dijelaskan juga dalam penyuluhan ini. Peserta penyuluhan terdiri dari kelompok tani/ternak serta masyarakat Kampung Matoa.
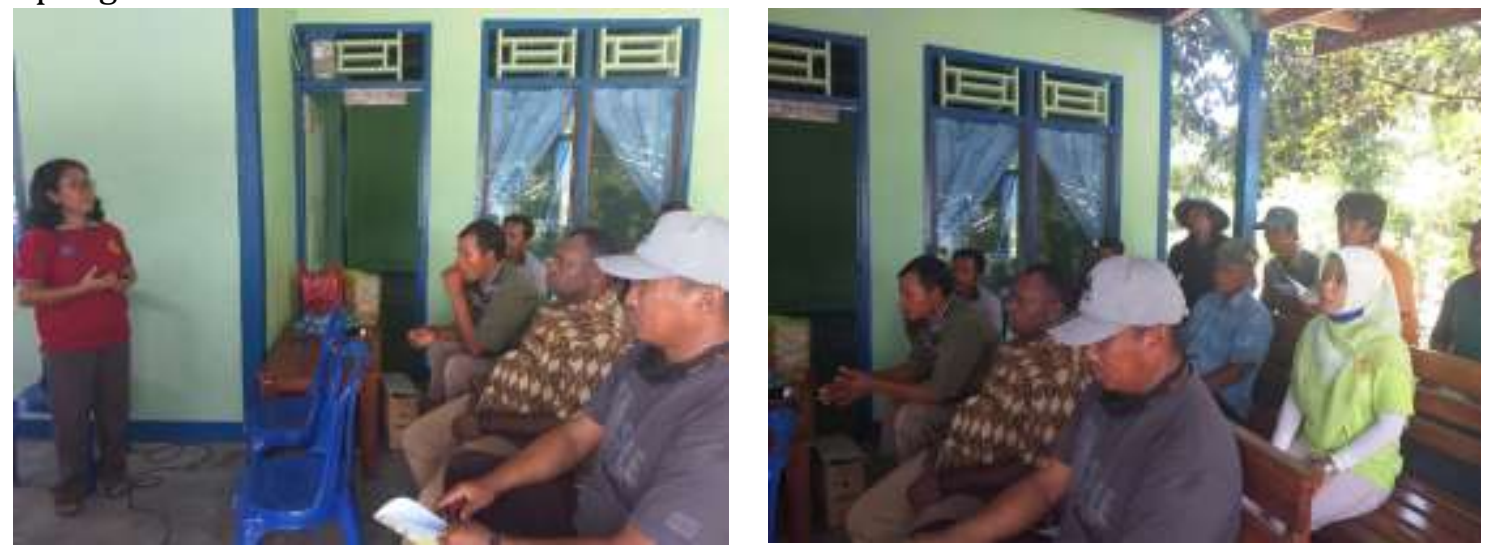

Gambar 1. Kegiatan penyuluhan pembuatan pupuk organik cair di Kampung Matoa

Peserta penyuluhan sangat antusias dan terlibat secara aktif selama kegiatan penyuluhan. Hal ini ditunjukan dengan adanya berbagai pertanyaan tentang dosis pupuk 
organik cair dan kandungan nutrisi utama yang terdapat pada pupuk organik cair. Selain itu peserta penyuluhan juga menanyakan kelebihan POC berbahan baku feses kambing dibandingkan dengan feses ternak yang lain. Pertanyaan lain yang diajukan oleh peserta penyuluhan adalah aplikasi POC berbahan baku feses kambing sebaikanya digunakan pada tanaman apa. Hal ini menunjukkan bahwa peserta penyuluhan memiliki keinginan dan minat besar untuk memanfaatkan feses kambing sebagai pupuk organik cair. Pemanfaatan feses kambing sebagai pupuk organik padat telah lama diaplikasikan petani/peternak, namun POC merupakan hal baru. Penjelasan kelebihan POC berbahan feses kambing yang mengandung $\mathrm{N}$ dan K dua kali lebih besar daripada feses sapi (Amri, 2019) dan tingginya kandungan unsur P pada feses kambing dibandingkan urin merupakan informasi penting bagi peternak yang selama ini mereka belum ketahui. Kandungan unsur N, P, K, C-organik, rasio C/N dan air pada kotoran kambing berturut-turut sebagai berikut 2,27 \%, 1,35 \%, 3,34 \%, 10,36 \%, 27,04, 27,04\% (Adhitya, 2017). Kelebihan lain POC adalah lebih mudah dimanfaatkan oleh tanaman karena unsur-unsur sudah terurai dan jumlah tidak terlalu banyak sehingga manfaatnya lebih cepat terasa (Pancapalaga, 2011) memberikan harapan bagi petani/peteranak dengan adanya POC dapat mengurangi biaya produksi pertanian.

Praktek pembuatan POC sangat menjadi aktivitas yang sangat menarik peserta penyuluhan. Pada kegiatan praktek pembuatan pupuk POC, peserta kegiatan terlibat secara aktif dalam mempersiapkan bahan yang diperlukan seperti mencacah daun gamal dan menyiapkan molases hingga pencampuran semua bahan dalam drum plastic (Gambar 2).
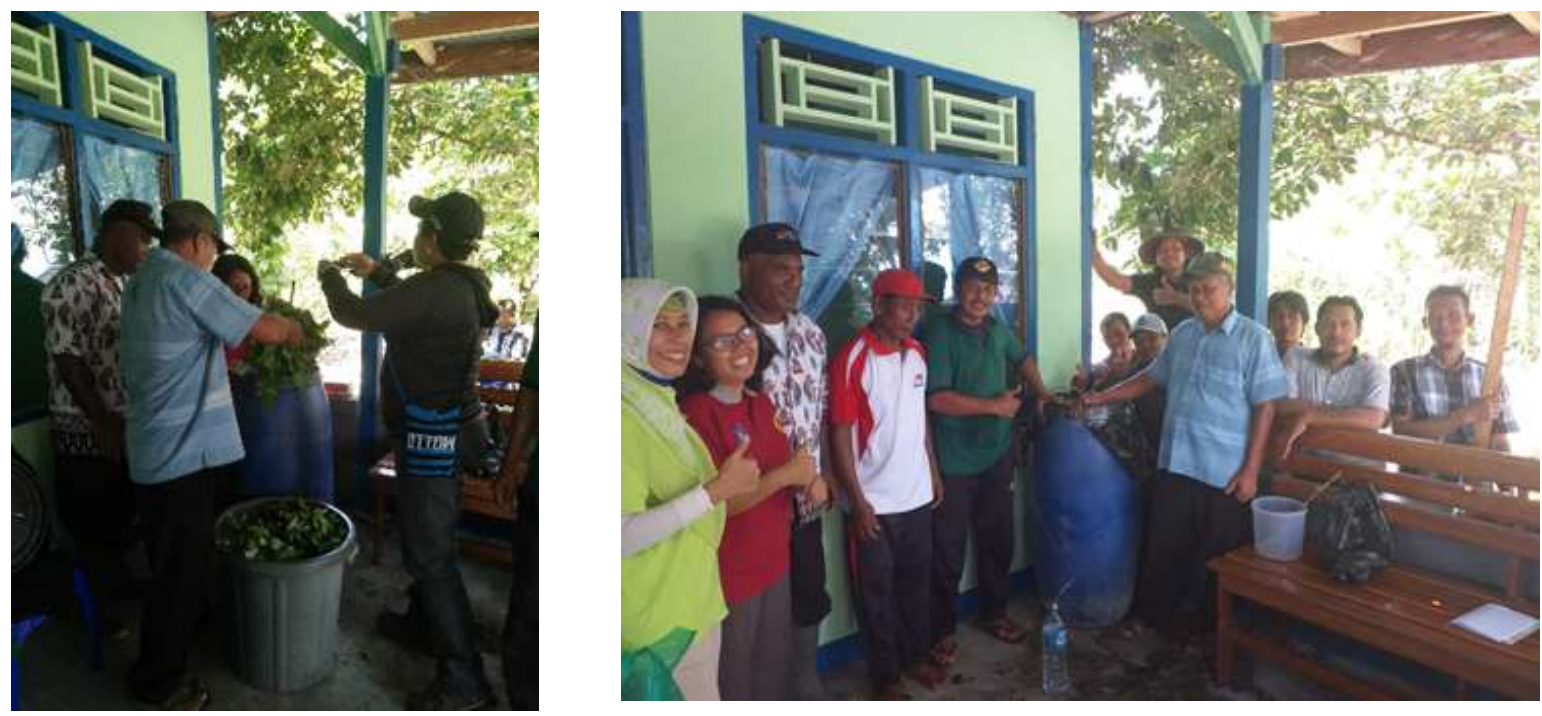

Gambar 2. Kegiatan praktek pembuatan Pupuk Organik Cair Bersama Peternak Kambing di Kampung Prafi Mulya dan Kampung Matoa

Pemanenan pupuk organik cair dilakukan tiga minggu setelah proses pembuatan. Waktu tiga minggu dianggap cukup untuk penguraian bahan-bahan yang digunakan dan proses fermentasi telah selesai. Pada waktu pemanenan dilakukan juga pengukuran jumlah pertikel dan konsentrasi terlarut dalam cairan POC dengan menggunakan TDS and EC meter hold digital. Hasil pengamatan menunjukkan jumlah partikel terlarut dalam POC hasil kegiatan ini sebesar $5669 \mu \mathrm{s} / \mathrm{cm}$. Hal ini menunjukkan jumlah partikel bahan organik yang terkandung dalam larutan POC cukup tinggi. Hasil kegiatan praktek pembuatan POC berupa produk pupuk yaitu pupuk organik cair. Pupuk POC tersebut diperoleh dengan menyaring cairan hasil fermentasi kemudian diisi ke dalam jerigen dan botol-botol (Gambar 3.) untuk selanjutnya dibagikan kepada kelompok petani peternak yang terlibat dalam kegiatan pembuatan POC. Pupuk organik cair yang dihasilkan pada kegiatan ini sebanyak \pm 100 liter. Dosis penggunaan POC untuk berbagai jenis tanaman sebanyak 15-30 liter/ha sesuai dengan jenis tanaman dan aplikasinya. Apabila asumsi penggunaan pupuk cair per ha sebanyak 20 liter, maka produksi POC yang dihasilkan pada kegiatan ini dapat digunakan untuk 5 hektar lahan sayuran seperti kangkung, 
bayam dan sawi. Apabila asumsi penjualan POC dengan harga Rp. 10.000/botol (1500ml) dapat menghasilkan lebih dari Rp 6,5 juta untuk sekali panen pada pembuatan POC dengan kaspasitas drum plastik 250 liter. POC yang dihasilkan dalam kegiatan ini telah diaplikasikan pada tanaman sawi dengan dosis $15 \mathrm{cc} /$ liter air. Gambar 3 adalah contoh tanaman sawi yang dipupuk dengan menggunakan POC berbahan baku feses kambing dan gamal. Sayur sawi yang dipupuk dengan POC hasil kegiatan terlihat subur dan hijau. Pemupukan dilakukan pada umur 21 HST dan diulangi setiap 2 minggu.
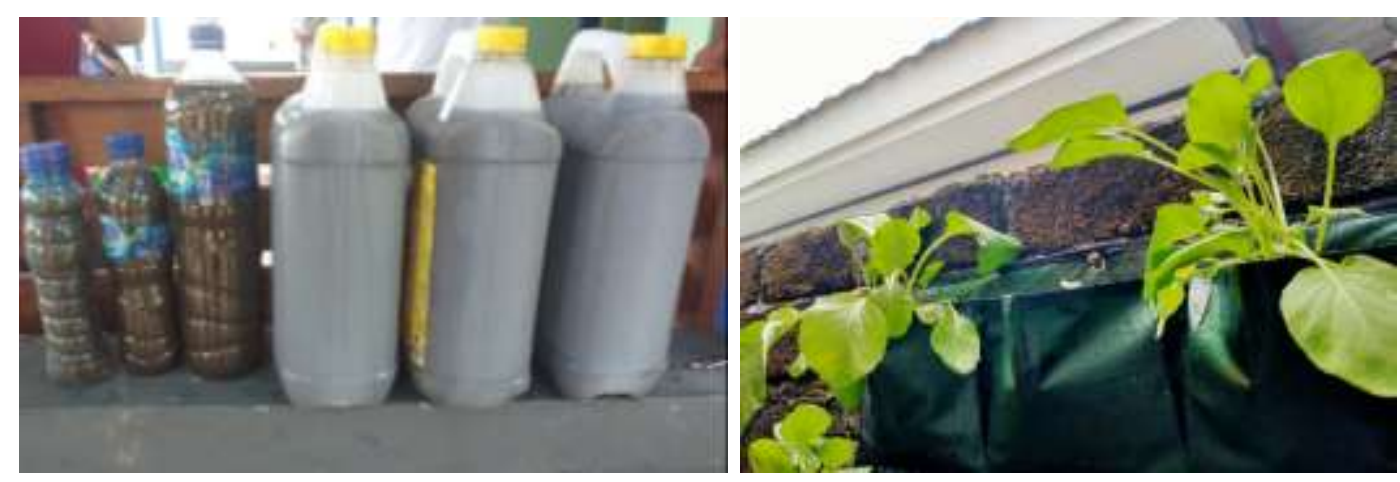

Gambar 3. Produk POC berbahan baku feses kambing dan daun gamal serta sayuran sawi yang mendapat permupukan POC

\section{KESIMPULAN}

Kegiatan pengabdian pembuatan pupuk organik cair di kampung Prafi Mulya dan Kampung Matoa dapat ditarik kesimpulan sebagai berikut:

1. Pemanfaatan kotoran kambing sebagai bahan baku POC merupakan sumber pupuk organik cair yang menunjang kegiatan pertanian masyarakat di Kampung Prafi Mulya dan Matoa Distrik Prafi Kabupaten Manokwari Papua Barat.

2. Kegiatan ini dapat mengatasi keterbatasan pupuk pada tanaman pertanian seperti sawi, kangkung dan bayam dan mengurangi biaya produksi pertanian.

3. Produk POC yang dihasilkan dapat menjadi tambahan sumber penghasilan dengan sedikit pengemasan.

Saran

Pendampingan pada petani/peternak dalam pemanfaatan POC perlu dilakukan secara terus menerus untuk menjamin keberlanjutan pemanfaatan pupuk organik sebagai sumber utama pupuk dalam kegiatan pertanian. Ketergantungan pada pupuk anorganik pada masa yang cukup lama berdampak negaif pada lahan pertanian.

\section{UCAPAN TERIMA KASIH}

Penulis mengucapkan terima kasih kepada Kemenristek/BRIN yang telah memberi dukungan finansial untuk kegiatan pengabdian ini.

\section{DAFTAR PUSTAKA}

Adhitya, Y., P. 2017. Optimalisasi Waktu Pengomposan dan Kualitas Pupuk Kandang dari Kotoran Kambing dan Debu Sabut Kelapa dengan Bioaktivator PROMI dan Orgadec. Balai Penelitian Tanaman Palma Jalan Raya Mapanget. Manado. 
AMRI, K. 2019. Upaya Meningkatkan Pertumbuhan Dan Produksi Kacang Kedelai (Glycine max) Dengan Pemberian Kompos Kotoran Kambing Dan POC Kulit Pisang. Kumpulan Karya Ilmiah Mahasiswa Fakultas sains dan Tekhnologi, 1(1), 429-429.

Alakhyar, Alakhyar, Fahrurrozi, Fahrurrozi, Widodo, Widodo, Sari, Dia Novita. 2019. 'Use Of Gliricidia-Enriched Liquid Organic Fertilizer For Production Of Caisim (Brassica juncea L.)', Jurnal Agroqua: Media Informasi Agronomi dan Budidaya Perairan, vol. 17, no. 1, pp. 1-7.

Hanisar, W 2015, 'Pengaruh Pemberian Pupuk Organik Cair terhadap Pertumbuhan dan Hasil Beberapa Varietas Kacang Hijau (Vigna radiata L.)', Universitas PGRI Yogyakarta. Skripsi

Napilia, M 2017, 'Pengaruh Penggunaan Pupuk Organik Cair Limbah Kulit Pisang Kepok dan Penggunaan Pupuk Kompos Limbah Rumah Makan Terhadap Pertumbuhan dan Produksi Tanaman Petsai (Brassica Chinensis L)'. Universias Medan Area. Skripsi. http://repository.uma.ac.id/handle/123456789/8395

Nurwati, N., Siswati, L., \& Mufti, M. (2017). Pelatihan Pembuatan Pupuk Organik Dari Kotoran Sapi di Kelurahan Tebing Tinggi Okura Kota Pekanbaru. Dinamisia : Jurnal Pengabdian Kepada Masyarakat, 1(1), 84-89. https://doi.org/10.31849/dinamisia.v1i1.424

Prastyo, JA 2015, 'pengaruh Pupuk Organik Cair (Poc) Bonggol Pisang Terhadap Pertumbuhan Dan Hasil Tanaman Kubis Bunga (Brassica oleraceae L.)', University of Muhammadiyah Malang. Skripsi

Setiyowati, Setiyowati, Haryanti, Sri, Hastuti, Rini Bud. 2010, 'Pengaruh perbedaan konsentrasi pupuk organik cair tehadap produksi bawang merah (Allium ascalonicum L)', Bioma: Berkala Ilmiah Biologi, vol. 12, no. 2, pp. 44-8.

Simanungkalit, RDM, Suriadikarta, Didi Ardi, Saraswati, Rasti, Setyorini, Diah, Hartatik, Wiwik. 2006, Pupuk organik dan pupuk hayati, Balai Besar Penelitian dan Pengembangan Sumberdaya Lahan Pertanian. Balai Penelitian dan Pengembangan Pertanian.

Sutedjo, M.M. 2010. Pupuk dan Cara Pemupukan. Rineka Cipta. Jakarta. 